\title{
Coastal upwelling in the eastern Gulf of California
}

\author{
Salvador-Emilio LLUCH-COTA *
}

Centro de Investigaciones Biológicas del Noroeste, S.C. PO Box 128 La Paz, BCS, México 23000

Received 11 May 1999; revised 8 December 1999; accepted 13 December 1999

\begin{abstract}
Understanding and quantifying upwelling is of great importance for marine resource management. Direct measurement of this process is extremely difficult and observed time-series do not exist. However, proxies are commonly derived from different data; most commonly wind-derived. A local wind-derived coastal upwelling index (CUI) is reported for the period 1970-1996 and is considered representative for the eastern central Gulf of California, an important fishing area where no proxies exist. The index is well related to pigment concentration distribution, surface water temperature, and population dynamics of important fish resources over the seasonal time-scale. There is a biological response to ENSO activity not reflected by this index, indicating that improvement of biological enrichment forecasting also requires water column structure input. A clearly increasing seasonal amplitude signal is detected in the coastal upwelling index and sea surface temperature since the mid 1970s. Understanding the nature of these long-term trends, the incorporation of remote tropical ocean signals into the enrichment proxy, the dynamics of atmosphere and ocean, and the biological responses are major challenges to the proper management of fish resources in the Gulf of California.
\end{abstract}

upwelling / Gulf of California / seasonality / climate change

Résumé - Upwelling côtier dans l'est du golfe de Californie. Comprendre et évaluer le phénomène d'upwelling est très important pour la gestion des ressources marines. Les mesures directes sont extrêmement difficiles et aucune série temporelle d'observations n'est disponible, mais des estimations sont possibles à partir de données telles que la vitesse du vent. Un indice d'upwelling côtier (CUI), déterminé dans le présent travail à partir du vent local pour la période 1970-1996, est représentatif de l'upwelling dans l'est du golfe de Californie où se trouve une importante zone de pêche. L'indice est en bon accord, à l'échelle de la saison, avec la répartition des concentrations en pigments, avec la température superficielle de l'eau et la dynamique des populations des ressources halieutiques. La réponse biologique au phénomène ENSO n'apparaît pas dans cet indice, ce qui montre que les apports dans la colonne d'eau doivent être pris en compte pour améliorer la prévision de la fertilité biologique. Un signal saisonnier d'amplitude nettement croissante est observé dans l'indice d'upwelling côtier et dans la température superficielle de l'eau depuis le milieu des années 70. Comprendre la nature des ces tendances à long terme, incorporer les signaux en provenance de l'océan tropical dans l'évaluation de la fertilité, dans la dynamique de l'atmosphère et de l'océan, et dans les réponses biologiques sont les défis majeurs à relever pour gérer correctement les ressources halieutiques du golfe de Californie. C) 2000 Ifremer/CNRS/IRD/Éditions scientifiques et médicales Elsevier SAS

upwelling / golfe de Californie / variabilité saisonnière / changement climatique

\section{INTRODUCTION}

* Correspondence and reprints:

E-mail address: slluch@cibnor.mx (S.-E. LLUCH-COTA)

Frictional stress of wind on the ocean surface, acting together with the earth's rotation, causes water flow

(C) 2000 Ifremer/CNRS/IRD/Éditions scientifiques et médicales Elsevier SAS

PII: S $0399-1784$ ( 00$) 00121$ - 3/FLA 
in the surface layer to deviate to the right in the northern hemisphere and to the left in the southern. When the direction of the transported water is directly offshore, water from beneath the surface upwells to replace it [4]. If pumping is strong enough to break the thermocline, the upwelled waters are normally nutrient-rich and, once in the photic zone, highly productive. Upwelling areas thus support large standing crops of plankton, massive fish stocks, and major populations of marine mammals and sea birds [26]. As a result, changes in upwelling over different time-scales, linked to variations in the atmospheric system and water column structure, are related to variability in fish populations and other components of the coastal ocean systems [7, 11, 20]. Understanding and quantifying upwelling activity is of great importance for marine resource management in such areas.

Directly quantifying coastal upwelling is extremely difficult, and observed time-series of the phenomenon do not exist [26]. However, useful proxies have been developed by processing different types of data. One possibility is to estimate upwelling by looking at its consequences on common locally-measured variables such as sea surface temperature (SST) and the structure of the ocean surface as derived from satellite imagery $[1,12]$.

A second approach is to look at the upwelling forcing agents. Bakun [4] first described and computed upwelling indices for the west coast of North America. From pressure grid data he estimated geostrophic winds, wind stress, and Ekman transport, and presumed perpendicular offshore transport to be proportional to upwelling. Other Ekman transport-derived indices have been computed using locally-measured winds by coastal stations [8] and by ships at sea [9].

Upwelling indices have been used in studies of ocean circulation, ENSO and climate change, linkages between environmental and biological variability and fisheries oceanography in several areas of the world ocean, especially where important marine fisheries exist $[6,26]$.

\subsection{The Gulf of California}

The Gulf of California (figure 1) is a long, narrow sea between the mainland of Mexico and the Baja Cali- fornia peninsula. Meteorologically and oceanographically it is regarded as a semi-enclosed basin because it is almost completely surrounded by elevated topography and connected to the open ocean only at its southern end [3]. These properties, together with it being in the tropical-subtropical transitional zone, result in a complex atmospheric and oceanographic environment, and in intense intraannual variations of physical and biological processes.

Atmospheric forcing is characterized by weak southeasterly winds in summer and stronger northwesterly winds in winter [21]. During both periods, winds are polarized along the gulf axis by an orographic effect [17]. Wind forcing, acting along with tides, solar heating and interactions with the open Pacific Ocean, creates a vigorous circulation in the gulf [2]. Recently modelled sea surface circulation [10] has shown an incoming flux and an outgoing one intensified along the coasts, with anticyclonic circulation during winter and cyclonic circulation during summer (figure 1). This pattern is confirmed by previous geostrophic calculations, drift observations, and suggested from surface thermal patterns observed from satellites [2, $16,19]$.

High primary productivity levels in the gulf result from an efficient nutrient transport of waters from under a shallow pycnocline into the euphotic zone [28], favouring the presence and reproduction of massive populations of species like the Pacific sardine (Sardinops sagax), one of Mexico's most important fisheries, accounting for the largest catch and providing many jobs. This nutrient enrichment is mainly driven by two mechanisms; a permanent, vertical mixing system because of strong tidal currents around the region of the larger islands (Tiburón and Angel de la Guarda) [2] and coastal, wind-driven upwelling [22].

Wind is likely to produce coastal upwelling throughout the year. However, only in winter, on the continental side, has a persistent and effective pump of nutrient rich waters to the surface been recognized $[16,19]$. Summer upwelling is absent or less effective because of a deeper thermocline and weaker winds, a narrower shelf on the peninsular side, and because on the western side of the gulf winds and sea surface currents flow in the opposite direction.

Despite its importance as a major environmental factor affecting biological population dynamics, there 
are no proxies of upwelling activity to allow the study of its variability and relationship to marine populations. In this contribution, an upwelling index for the eastern coast of the central Gulf of California is computed and compared to pigment concentration distribution derived from satellite data. Some preliminary observations on the variability of the upwelling are also provided.

\section{MATERIALS AND METHODS}

Sparsity of adequate quality data is a major problem when analyzing environmental properties and variability of the Gulf of California; monitoring is in early stages of development and only a few sparse
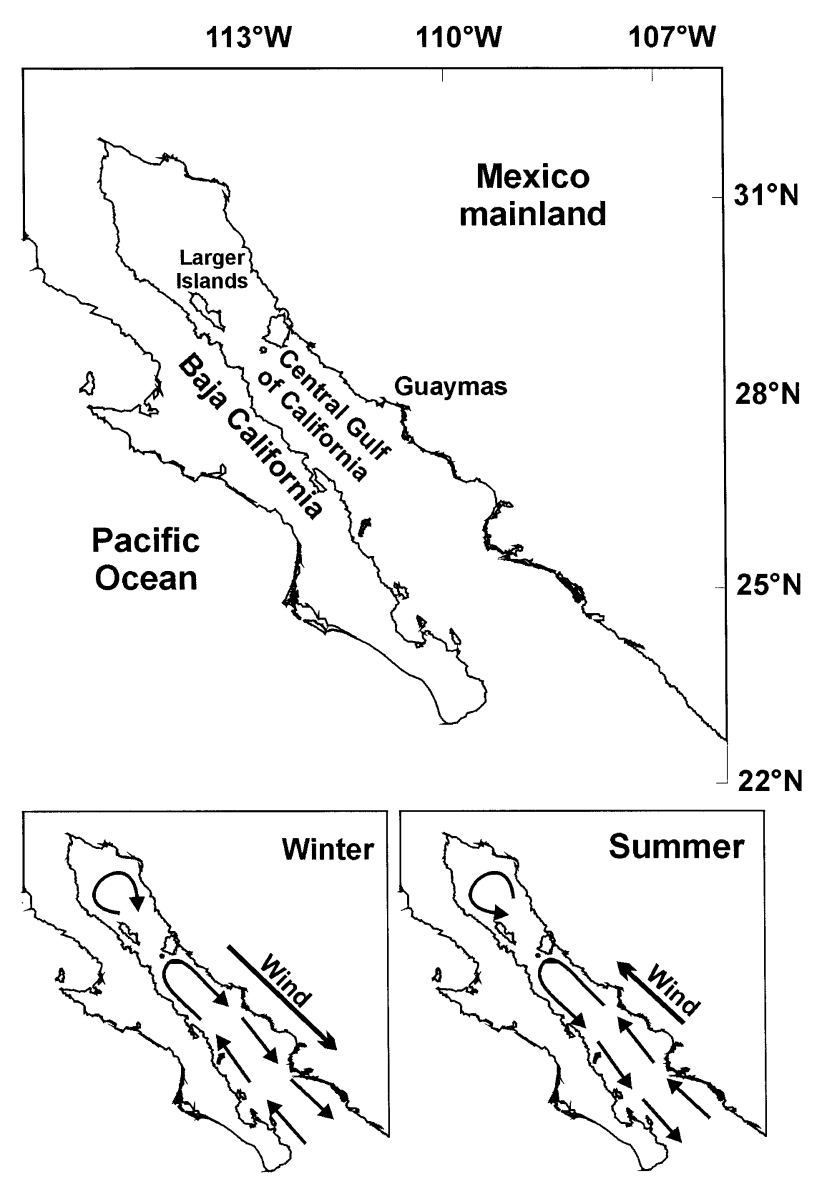

Schematic ocean surface circulation

Figure 1. The Gulf of California and schematic winter and summer ocean surface circulation patterns. data in time and space are available from research programs. Data for the gulf included in world-wide coverage databases, such as the Comprehensive Ocean-Atmosphere Data Set (COADS) [23] that summarizes over $10^{8}$ surface meteorological observations collected by ships of opportunity and other platforms [24], are sometimes enough to draw up an idea of the seasonal behaviour, but are almost useless for building time-series. An additional problem is that synoptic estimates such as mean pressure fields (such as those provided by the U.S. Navy Fleet Numerical Meteorology and Oceanography Center) are commonly available in grid scales larger than convenient for the width of the gulf. Locally-measured wind data seems to be an alternative for computing an upwelling index for this region considering the topographically polarized wind circulation. However, caution should be used when looking at precise short-term readings.

Daily wind data generated at 1900 hours at the Empalme station of the National Meteorological Service (SMN) near Guaymas, Son., on the continental side of the central Gulf of California (figure 1), were digitized. This time of day was chosen because no hourly data exists for the entire time period, and it is likely to consistently represent dominant wind conditions for most of the daily cycle (Nevárez-Martínez, CRIP-Guaymas, pers. comm.).

Computations follow those of Bakun [4]. Wind stress for each daily wind value was estimated using:

$\vec{\tau}=\rho \mathrm{Cd}|\vec{V}| \vec{V}$

where $\tau$ is the stress vector, the density of the air (considered constant at $0.0012 \mathrm{~g} \cdot \mathrm{cm}^{-3}$ ), $C_{D}$ is an empirical drag coefficient (considered constant at $0.0013), V$ is the scalar wind speed, and $V$ is the vector wind velocity. Vector averages were computed from the daily wind stress values for each calendar month and net transport estimated for the layer of some several tens of metres beneath the surface based on the simplified idealization known as Ekman transport $(M)$ :

$\vec{M}=(1 / f) \vec{\tau} \times \vec{k}$

where $k$ is a unit vector directed vertically upward, denotes the wind stress vector, and $f$ is the Coriolis parameter (approximately $6.8 \times 10^{-5}$ at the Empalme latitude). Since the volume of water transported off- 
shore perpendicular to the coast $\left(\mathrm{M}_{\mathrm{x}}\right.$, where $\mathrm{x}$ is normal to the coastline) is proportional to the volume of upwelled water, the Coastal Upwelling Index at Empalme (CUI) is computed as the negative $\mathrm{M}_{\mathrm{x}}$ value $\left(\mathrm{CUI}=-\mathrm{M}_{\mathrm{x}}\right)$.

Monthly values of the CUI time-series were used to identify the seasonal signal by estimating the monthly averages for the year. Time-series were also built for summer (July to September average), winter (December to February average) and seasonal amplitude (winter-summer).

As a biologically relevant consequence of upwelling, pigment concentration distribution was analyzed from 96 regional-scale monthly composites (November 1978 to June 1986) as extracted from the NASA Jet Propulsion Laboratory, Physical Oceanography Distributed Active Archive Center CD-ROM [27]. The annual cycle at each pixel for the entire gulf (a total of 650 pixels) was estimated and a cluster analysis was used to identify mesoscale regions with similar seasonal signals. Three latitudinal regions were found (figure 2), one of them the central gulf (from the southern limit of the larger islands south to nearly $25^{\circ} \mathrm{N}$ ). The original monthly values of the pixels within this region were geometrically averaged to build a time-series of pigment concentration and to calculate the seasonal cycle. The use of the CUI as a proxy for biological enrichment was explored by expressing the monthly pigment-concentration time-series as an exponential function of the CUI. The upwelling development was tracked as reflected by phytoplankton distribution during the average year by plotting the twelve average matrices as isolines of pigment concentration.

Monthly 1968 to 1995 surface-temperature series for the $1^{\circ} \times 1^{\circ}$ quadrant centred at $111.5^{\circ} \mathrm{W}$ and $27.5^{\circ} \mathrm{N}$ (central Gulf of California) were kindly provided by Dr A. Douglas (Atmospheric Sciences Department, Creighton University). Previous analyses have shown that most of the boxes from the gulf do show similar tendencies in seasonal, interannual, and longer timescales (Salinas-Zavala, CIBNOR, pers. comm.).

Interannual variability was explored by comparing winter (December to February) values of the Southern Oscillation Index and the CUI anomalies. Exponential functions were fitted to the entire time period and to ENSO months as reflected in pigment concentration (from April 1983 through October 1994, according to
Lluch-Cota, unpublished data) and non-ENSO months (rest of the series). Linear regressions were also fitted to winter, summer, and seasonal amplitude time-series of SST and CUI.

\section{RESULTS AND DISCUSSION}

Coastal-upwelling-index series for the east coast of the central Gulf of California are shown in figure 3. Using an exponential function, we are able to significantly $(r=0.704, P<0.05)$ relate pigment concentration for the central Gulf of California to CUI (figure 4).

By simple observation of the series, we can distinguish three main features; the strong seasonal behaviour, the lack of evident ENSO-related signals, and an increasing trend in the seasonal intensity through the study period.

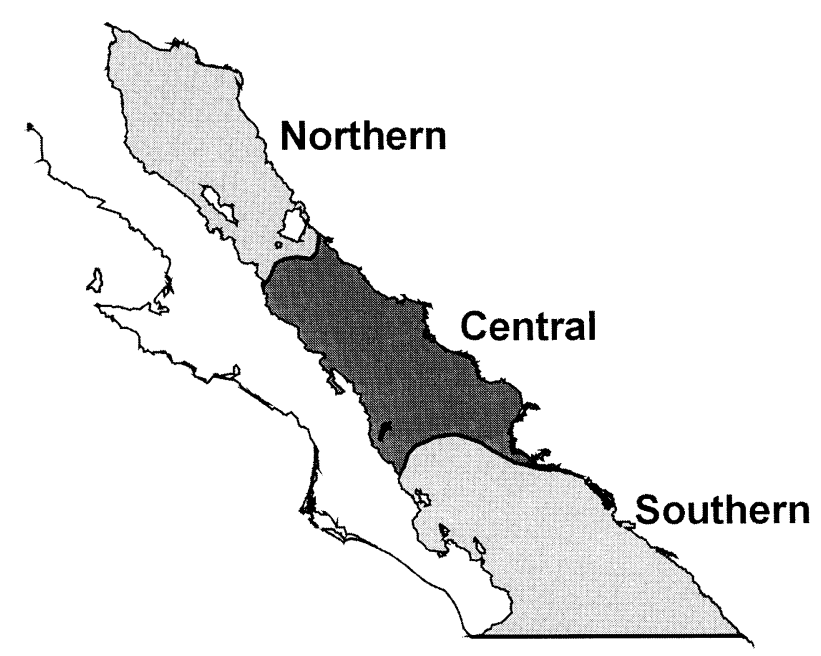

Figure 2. Regions resulting from a cluster analyses of annual cycles of pigment concentration (CZCS) at each pixel for the entire gulf.

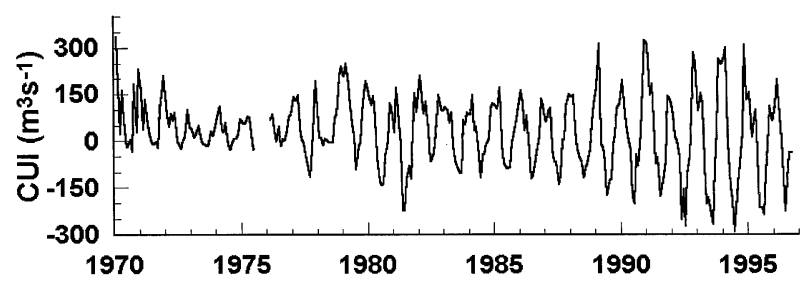

Figure 3. Coastal Upwelling Index time-series for 1970 to 1996. 


\subsection{Seasonality}

Figure 5 shows the pattern of the biological enrichment in the Central Gulf of California during the average year, as reflected by satellite-derived pigmentconcentration isolines. During November and December pigment-rich water begins to occupy the central area from the northern continental side to the southern western coast. During summer, there is a contraction of the enriched area from southeast to northwest, where a small area of high pigment concentration remains year-round.

The CUI shows a seasonal pattern (figure 6a) peaking during December-January, when the lowest monthly values of sea surface temperature (figure $6 b$ ) and highest pigment concentration levels (figure 6c) occur. This is consistent with previous observations [2, 19, 22].

In contrast to open oceanic upwelling areas where phytoplankton biomass is advected off the coast creating an inshore-offshore concentration gradient, in the Gulf of California in winter, very rich waters originating close to the islands and the upwelling on the east coast remained trapped, which contributes to increased production per unit area in the central gulf [13]. From previous studies, it is likely that winter

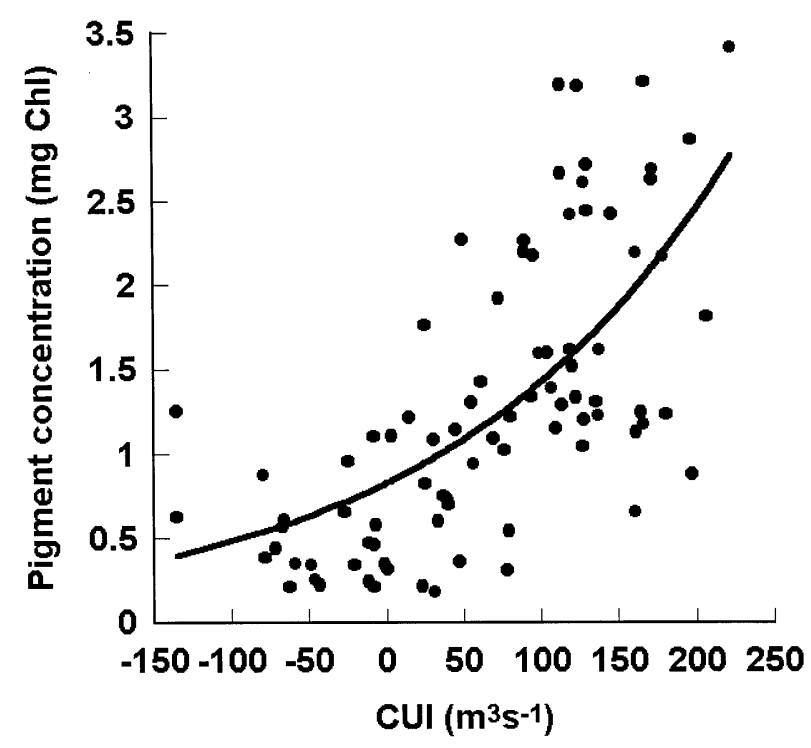

Figure 4. Exponential relationship between the Coastal Upwelling Index and pigment concentration in the central Gulf of California. upwelling clearly provides an enriched, cool habitat for sardine spawning. Hammann et al. [14], by analyzing sardine eggs and larvae information from 38 research cruises (1965-57 and 1971-1991), recently demonstrated that sardine tend to spawn from November to May, peaking during December and January. Furthermore, he found that contrary to common belief, sardines spawn all over the gulf, but more frequently and intensively in the central region.

\subsection{Interannual}

No significant correlations were found between the Southern Oscillation Index (SOI) and CUI anomalies in any time lag (from 0 to 12 months; results not shown). Winter series (figure 7) show no coherence, indicating that atmospheric forcing in the central gulf is not directly influenced by ENSO, even during major events like 1982-1983.

The effects of ENSO activity on primary biological production in the gulf is not yet fully understood. By analyzing field data, Valdez-Holguín and Lara-Lara [28] concluded that during the 1982-1983 ENSO there was no decrease in the primary production rate, but an increase caused by diminished predation pressure. Santamaría et al. [25] analyzed time-series at geographically fixed pixels of Coastal Zone Color Scanner (CZCS) imagery and found no relation between ENSOs and concentrations in the central gulf. However, other CZCS-derived data analyses have shown that, at least during the 1982-1983 event, pigment concentration decreased in that area during the second half of the ENSO and remained low until late 1984 (Lluch-Cota, unpubl. data), coinciding with observations by Zuria-Jordán et al. [29].

Figure 8 shows pigment concentration as a function of CUI for two scenarios (ENSO and non-ENSO months). Fitted exponential functions show similar slopes for the two curves (table I), with similar values of wind forcing (CUI) but a different phytoplankton response level (nearly $0.5 \mathrm{mg} \mathrm{Chl}$ ). The CUI is actually an atmospheric index (wind-derived) and the Gulf of California is located in a region where atmospheric teleconnections related to ENSO are not operating (at least in a direct manner, similar to that of higher latitudes) and thus major ENSO-related 

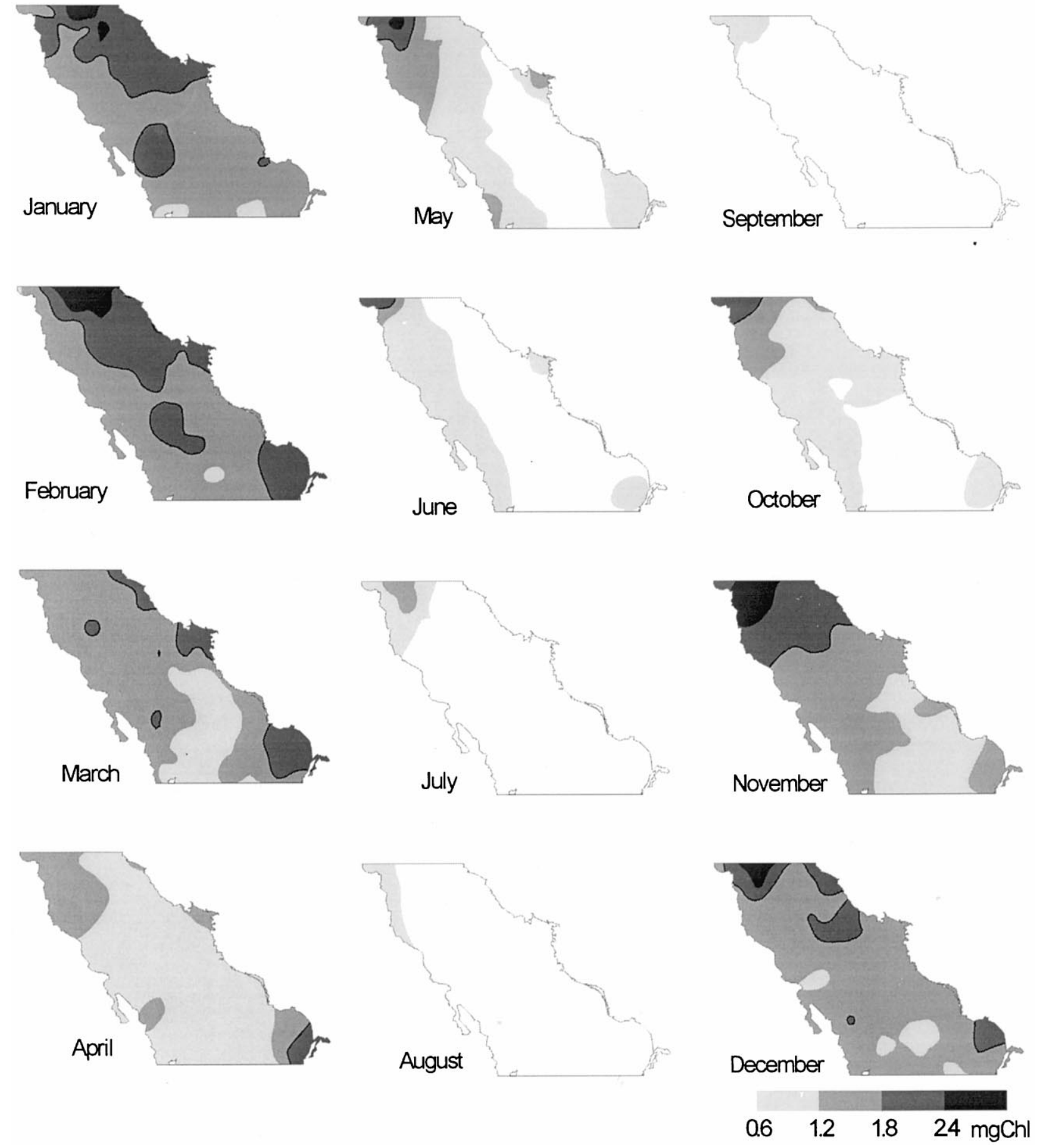

Figure 5. Track of the biological enrichment in the Central Gulf of California during the average year as reflected by satellite-derived pigment-concentration isolines. 
forcing comes through the ocean (coastal Kelvin waves). Upwelling activity is mostly normal but hardly reaches the deeper-than-normal thermocline and lower nutrient enrichment takes place. It is likely that improving the CUI forecasting capabilities on an interannual scale will demand the integration of the wind-forcing signal with water-column-structure information.
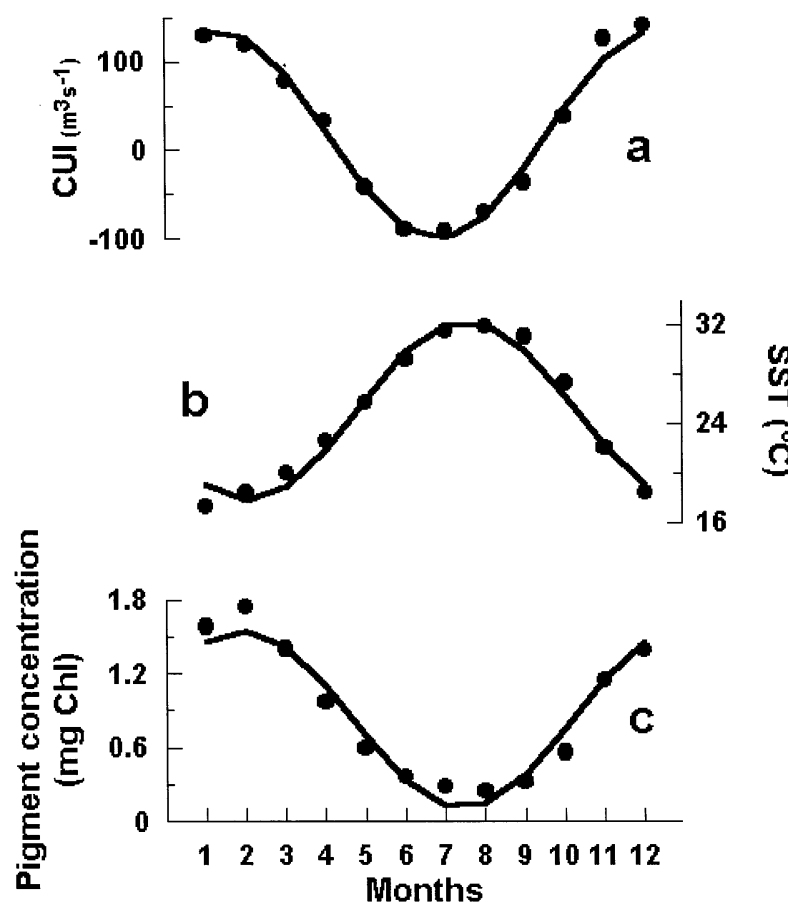

Figure 6. Average seasonal cycle for the CUI, sea surface temperature, and pigment concentration in the central Gulf of California. Observed averages (dots) and single-cycle single-harmonic cyclical fit (lines).

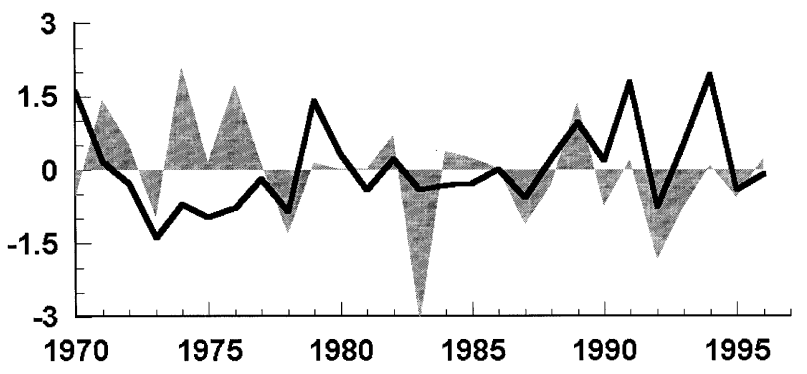

Figure 7. Winter (December to February) standardized series of the SOI (shadow) and the CUI anomalies (line).

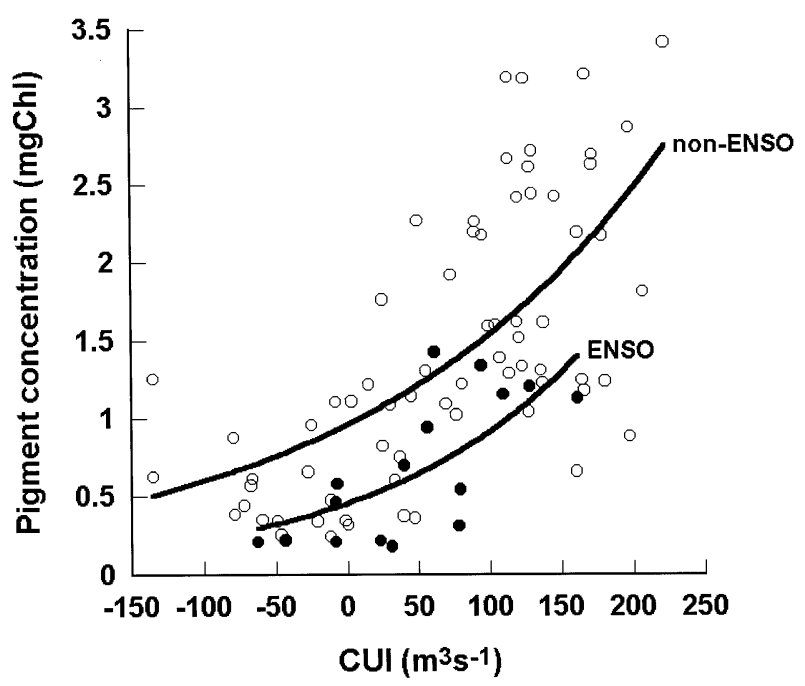

Figure 8. Exponential relation between the CUI and pigment concentration in the central Gulf of California during non-ENSO (open circles, upper curve) and ENSO months (closed circles, lower curve).

\subsection{Long-term trend}

Figure 9 shows transformed CUI and SST time series. Though long time-scale changes could not be properly reflected because of the series length, there is a clearly increasing trend of positive upwelling values during the winter and negative during the summer since the mid-1970s. This signal is best shown in panel $\mathrm{c}$ as seasonal signal intensity over time (wintersummer) where differences between extreme seasons rise from around $100 \mathrm{~m}^{3} \cdot \mathrm{s}^{-1}$ in 1975 to near 400 $\mathrm{m}^{3} \cdot \mathrm{s}^{-1}$ in 1995. Moreover, the SST series (independent from the CUI series) also shows this trend during the same period (figure 9, panels d, e, f; table II)

Bakun [5] noted that one likely consequence of global warming is the increase in the temperature gradient between oceans and continents during the springsummer, with consequent increased alongshore wind circulation and upwelling activity. The baseline of this mechanism is the increase in the atmospheric pressure gradient between regions where low-high cells produce geostrophic winds. In the Gulf of California, winter is mainly characterized by a high pressure field on the Pacific side and low on land, producing northwesterlies in the same basic manner as those along the California coast [15]. During sum- 
Table I. Values and correlation coefficients $(P<0.05)$ for the exponential function of pigment concentration and CUI for the entire period (1978-1986), for non-ENSO months, and ENSO months (April 1983-October 1984).

\begin{tabular}{lccc}
\hline & Complete series & Non-ENSO months & ENSO months \\
\hline Constant & 0.826 & 0.959 & 0.456 \\
Slope & 0.005 & 0.005 & 0.007 \\
standard error & 0.637 & 0.646 & 0.335 \\
Correlation coefficient & 0.669 & 0.665 & 0.701 \\
Degrees of freedom & 84 & 68 & 15 \\
\hline
\end{tabular}

mer, when winds blow from the south, the configuration is totally different to that of the Pacific coast; circulation being driven by differences between the low pressure field above the gulf and a relatively high inland cell [18]. This way, cooler winters and warmer summers would augment the gradient during both seasons and increased wind velocities are to be expected year round. Whereas the basic Bakun mechanism is likely to be operating in the gulf, further research and longer time-series are needed to achieve solid conclusions.

Clarifying whether the increase in the seasonal intensity of SST and upwelling is a response to global warming, decadal basin-scale, regional-scale variability, or a combination of these is beyond the scope of this contribution. Gaining further understanding of these changes depends on our ability to study the ocean-atmosphere dynamics operating in the Gulf of California, and identify the external forcing processes driving those dynamics.

\section{CONCLUSIONS}

A coastal upwelling index is reported for 1970-1996 representing the wind-driven enrichment in the east central Gulf of California during the winter, as demonstrated from a pigment concentration distribution analysis. On the seasonal time-scale, the index is well related to SST and pigment concentration, and is likely to be also related to the population dynamics of important fish resources. That there is a biological response to ENSO activity not reflected by this atmospherically derived index has been demonstrated, indicating that improvement of biological-enrichment-forecasting capabilities demands also watercolumn-structure input. An increasing trend in the seasonal amplitude has been suggested in the CUI and SST since the mid-1970s.
Investigating the nature of those long-term trends, the incorporation of remote tropical ocean signals into the enrichment proxy, and further understanding the dynamics of atmosphere, ocean, and biological responses are major challenges to be accomplished to properly manage fish resources in the Gulf of California.

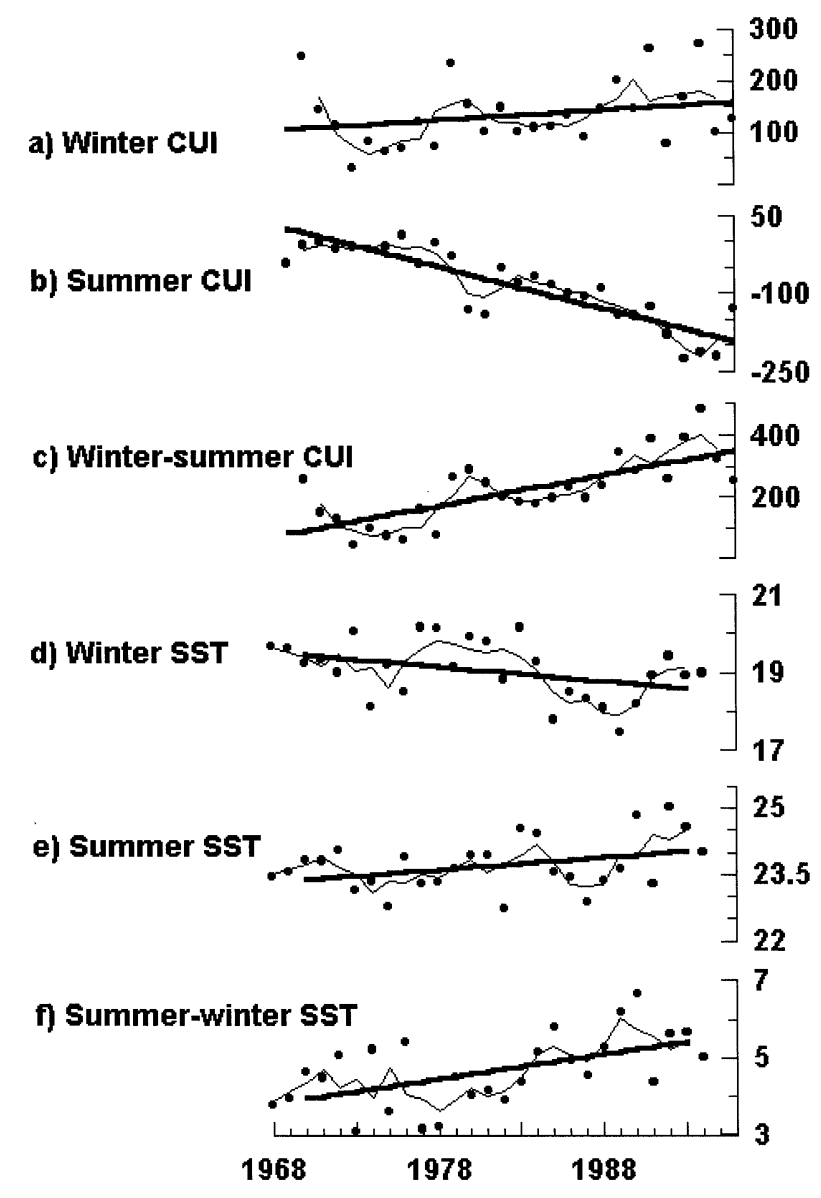

Figure 9. Time-series of observed data (dots), centred threemonth moving average (curves) and long-term tendency for 19701996 (bold line). CUI values (panels a, b and c) in $\mathrm{m}^{3} \cdot \mathrm{s}^{-1}$ and SST values (panels $\mathrm{d}$, e and $\mathrm{f}$ ) in ${ }^{\circ} \mathrm{C}$. 
Table II. Long-term (linear regression) slopes for the original SST and CUI series, the standardized series, and correlation coefficients $(P<0.05)$

\begin{tabular}{lccc}
\hline & Slope original series & Slope standardized series & Correlation coefficient \\
\hline Winter SST & -0.037 & -0.050 & -0.352 \\
Summer SST & 0.028 & 0.047 & 0.336 \\
Summer-winter SST & 0.065 & 0.074 & 0.513 \\
Winter CUI & 2.053 & 0.034 & 0.261 \\
Summer CUI & -7.980 & -0.114 & -0.881 \\
Winter-summer CUI & 10.033 & 0.094 & 0.733 \\
\hline
\end{tabular}

\section{Acknowledgements}

This contribution was supported by grants CONACyT R-29374B, SIMAC 970106044, CIBNOR AYCG-7 and CONACyT scholarship 94964 . Valuable discussion was provided by A. Bakun (FAO), D. Lluch-Belda (CICIMAR), A. Parés-Sierra (CICESE), and A. Leyva-Contreras (UNAM). E. Glazier edited the English text.

\section{REFERENCES}

[1] Aman, A., Fofana, S., 1998. Spatial dynamics of the coastal upwelling off Côte-d'Ivoire. In: Durand, M.H., Cury, P., Mendelssohn, R., Roy, C., Bakun, A., Pauly, D. (Eds.), Global Versus Local Changes in Upwelling Systems. Orstom, Paris, pp. 139-147.

[2] Badan-Dangon, A., Koblinsky, D., Baumgartner, T., 1985. Spring and summer in the Gulf of California: observations of surface thermal patterns. Oceanol. Acta 8 (1), 13-22.

[3] Badan-Dangon, A., Dorman, C.E., Merrifield, M.A., Winant, C.D., 1991. The lower atmoshpere over the Gulf of California. J. Geophys. Res. 96, 16877-16896.

[4] Bakun A., 1973. Coastal upwelling indices, west coast of North America, 1946-1971, NOAA Tech. Rep. NMFS SSFR-671, 103 p.

[5] Bakun, A., 1990. Global climate change and intensification of coastal ocean upwelling. Science 247, 198-201.

[6] Bakun A., 1996. Patterns in the Ocean: Ocean Processes and Marine Population Dynamics, Univ. California Sea Grant in cooperation with Centro de Investigaciones Biológicas del Noroeste, La Paz, México, 323 p.

[7] Bakun, A., 1998. The CEOS comparative analysis framework: motivations and perceived opportunities. In: Durand, M.H., Cury, P., Mendelssohn, R., Roy, C., Bakun, A., Pauly, D. (Eds.), Global Versus Local Changes in Upwelling Systems. Orstom, Paris, pp. 2-26.

[8] Bakun A., Mendelssohn R., 1989. Alongshore wind stress, 1953-1984: correction, reconciliation and update through 1986, in: Pauly D., Muck P., Mendo J., Tsukayama I. (Eds.) The Peruvian Upwelling Ecosystem: Dynamics and Interactions, ICLARM Conference Proc. 18, 77-81.
[9] Bakun, A., Roy, C., Lluch-Cota, S.E., 1998. Coastal upwelling and other ecosystem processes controlling the marine resource productivity of the western Indian Ocean. In: Sherman, K., Okemwa, E.N., Ntiba, M. (Eds.), Large Marine Ecosystems of the Indian Ocean: Assessment, Sustainability and Management. Blackwell Science, Oxford, pp. 103-141.

[10] Beier, E., 1997. A numerical investigation of the annual variability in the Gulf of California. J. Phys. Oceanogr. 27, $615-632$.

[11] Cury P., Roy C., Mendelssohn R., Bakun A., Husby D.M., Parrish R.H., 1995. Moderate is better: nonlinear climatic effects on California anchovy, in: Beamish J.R. (Ed.), Climate Change and the Northern Fish Populations, Can. Spec. Pub. Fish. Aquat. Sci. 121, pp. 417-424.

[12] Demarcq, H., 1998. Spatial and temporal dynamics of the upwelling off Senegal and Mauritania: local change and trend. In: Durand, M.H., Cury, P., Mendelssohn, R., Roy, C., Bakun, A., Pauly, D. (Eds.), Global Versus Local Changes in Upwelling Systems. Orstom, Paris, pp. 149-165.

[13] Gaxiola-Castro, G., García-Córdova, J., Valdéz-Holguín, J.E., Botello-Rubalcaba, M., 1995. Spatial distribution of chlorophyll $a$ and primary productivity in relation to winter physical structure in the Gulf of California. Cont. Shelf Res. $15,1043-1059$.

[14] Hammann, G., Nevarez-Martínez, M.O., Green-Ruíz, Y., 1998. Spawning habitat of the Pacific sardine (Sardinops sagax) in the Gulf of California: egg and larval distribution 1956-1957 and 1972-1991. CalCOFI Rep. 39, 169-179.

[15] Hastings, J.R., Turner, R.M., 1965. Seasonal precipitation regimes in Baja California, Mexico. Geografiska Annaler 47A, 204-223.

[16] Lavín M.F., Beier E., Badan A., 1997. Estructura hidrográfica y circulación del Golfo de California: Escalas estacional e interanual, in: Lavín, M.F. (Ed.), Contribuciones a la Oceanografía Física de México, Monografía UGM 3, pp. 139-169.

[17] Merrifield, M.A., Winant, C.D., 1989. Shelf circulation in the Gulf of California: a description of the variability. J. Geophys. Res. 94, 18133-18160.

[18] Mosiño A.P., 1966. Factores que determinan el clima en la República Mexicana con referencia especial a las zonas áridas, SEP-INAH-Dep. de Prehistoria, Pub. No. 19, p. 22. 
[19] Paden, C., Abbott, M.R., Winant, C.D., 1991. Tidal and atmospheric forcing of the upper ocean in the Gulf of California 1, sea surface temperature variability. J. Geophys. Res. 96, $18337-18359$.

[20] Parrish, R.H., Nelson, C.S., Bakun, A., 1981. Transport mechanisms and reproductive success of fishes in the California Current. Biol. Oceanogr. 1, 175-203.

[21] Roden G.I., 1964. Oceanographic aspects of the Gulf of California, in: Van Andel T.H., Shor G.G. (Eds.), Marine Geology of the Gulf of California, Mem. Am. Ass. Petrol. Geol. 3, pp. $30-58$.

[22] Roden, G.I., Groves, G.W., 1959. Recent oceanographic investigations in the Gulf of California. J. Mar. Res. 18, 10-35.

[23] Roy C, Mendelssohn R., 1994. COADS on CD-ROM Vol. 5, Eastern Pacific, Surface Marine Observations database, NOAA/CEOS/ORSTOM, CD-ROM.

[24] Roy, C., Mendelssohn, R., 1998. The Development and the use of a climate database for CEOS using the COADS dataset. In: Durand, M.H., Cury, P., Mendelssohn, R., Roy, C., Bakun, A., Pauly, D. (Eds.), Global Versus Local Changes in Upwelling Systems. Orstom, Paris, pp. 27-44.
[25] Santamaría-del-Angel, E., Alvarez-Borrego, S., MüllerKarger, F.E., 1994. El Niño in the Gulf of California as seen in Coastal Zone Color Scanner imagery. J. Geophys. Res. 99, 7411-7421.

[26] Schwing F.B., O’Farrell M., Steger J., Baltz, K., 1996. Coastal upwelling indices, west coast of North America, 1946-1995. NOAA Tech. Mem. NMFS-SWFSC-231, $207 \mathrm{p}$.

[27] Tran A.V., Hyon J., Evans R., Brown O., Feldman G., 1993. Satellite-derived multichannel sea surface temperature and phytoplankton pigment concetration data: A CD-ROM set containing monthly mean distributions for global oceans, User manual of the USA_NASA_JPL_PODAAC_A001-A005 ver 1, p. 32

[28] Valdez-Holguín, J.E., Lara-Lara, R., 1987. Primary productivity in the Gulf of California effects of El Niño 1982-1983 event. Ci. Mar. 13, 34-50.

[29] Zuria-Jordán, I.L., Alvarez-Borrego, S., Santamaría-del-Angel, E., Müller-Karger, F.E., 1995. Estimación de la biomasa fitoplanctónica, derivada de datos de satélite, frente a Baja California Sur. Ci. Mar. 21, 265-280. 